\title{
Sustainability in Malaysian Palm Oil: A Review on Manufacturing Perspective
}

\author{
Ilyana Abdullah ${ }^{1 *}$, Wan Hasrulnizzam Wan Mahmood', \\ Muhammad Hafidz Fazli Md Fauadi', Mohd Nizam Ab Rahman², \\ Fathiyah Ahmad $^{3}$
}

${ }^{1}$ Sustainable and Responsive Manufacturing Research Group, Faculty of Manufacturing Engineering, Universiti Teknikal Malaysia Melaka, Hang Tuah Jaya, 76100, Durian Tunggal, Melaka, Malaysia

${ }^{2}$ Advanced Manufacturing Research Group, Faculty of Engineering and Built Environment,

Universiti Kebangsaan Malaysia, UKM Bangi 43600, Selangor, Malaysia

${ }^{3}$ Department of Language Studies, Universiti Technologi MARA Cawangan Kedah, P.O. Box 187, 08400 Merbok, Kedah, Malaysia

Received: 12 December 2014

Accepted: 15 March 2015

\begin{abstract}
The increasing worldwide demand of sustainable palm oil product has encouraged the industry to develop a sustainability strategy on the unintended social, environmental, and economic consequences of rapid population growth, economic growth, and consumption of natural resources. This study reviews the manufacturing perspective on the current sustainability effort and identifies the drivers for sustainability - particularly in Malaysia - that control almost 50 percent of the global export market share. It revealed current research on sustainability in general palm oil manufacturing (or palm oil mill) which involves empty fruit bunches, crude palm oil, crude palm kernel oil, the refinery process, and palm oil waste management. It also highlights the drivers for sustainability in the Malaysian palm oil industry. The findings of our study suggest that manufacturing sustainability in Malaysian palm oil manufacturing is driven by three main objectives: environmental consciousness, economic escalation, and social commitment - which all link to each other and demonstrate progress toward sustainability. Nevertheless, social commitment shows a lesser amount of publications among the drivers. This study can be helpful for palm oil organisations (particularly in Malaysia) to recognize their opportunities and threats in efforts to enhance business profiles, corporate reputations, and market growth without neglecting environmental and social impacts.
\end{abstract}

Keywords: Malaysia palm oil, sustainability, manufacturing perspective

\section{Introduction}

Sustainability as a concept is more comprehensive and systemic to maximize the welfare of the environment, economy, and society [1]. The concept uses both technological and non-technological solutions that include a selection of materials and production processes and life cycle engineering, as well as organizational mission, structure,

*e-mail: ilyana.abdullah2@gmail.com and performance. Manufacturing sustainability will constitute the foundation of the new clean, carbon-neutral global economy in the next three to five decades. These benefits also will create a competitive advantage for an organization and enhance its position in society as well as positive perception of customers and society [2].

The palm oil industry is well known as a significant agricultural industry in terms of economic benefit for several tropical countries, particularly in Malaysia [3]. Malaysia has a total of 426 mills actively producing 24.97 
million tonnes of crude palm oil per year, controlling over $46 \%$ of the global export market share [4]. The process of producing crude palm oil (CPO) has nevertheless generated a million tonnes of empty fruit bunches, fibre and palm shells, palm kernel endocarp, palm kernel press cake and liquid effluent, and palm oil mill effluent (POME) every year as waste [5]. Palm oil mills in Malaysia generate about 60 million tonnes of POME annually, which would be a major source of pollution if discharged directly into water sources [4]. As a consequence, the manufacturing process reduces freshwater and soil quality, and adversely affects local communities dependent on ecosystem products for food and medicines and ecosystem services such as regulation of the hydrological cycle and soil protection [6].

Palm oil production is, moreover, criticised for its high greenhouse gasses (GHG) impact. At the mill level, two main sources of GHG emissions are present: fossil fuel consumption and methane emission from POME in open anaerobic lagoons (although only the latter is significant at the supply chain level) [7]. It is estimated that methane emission from the palm oil industry in Malaysia is approximately 0.214 million tonnes [8], as well as the production and treatment of one ton of fresh fruit bunches (FFB) causing more than $460 \mathrm{~kg} \mathrm{CO}_{2}$ eq in the worst case scenario and $110 \mathrm{~kg} \mathrm{CO}$ eq in the best case scenario [9]. The POM processes have a long history of environmental challenges and leave a significant eco-footprint, including large quantities of polluted waste materials, GHG emissions, and biodiversity loss - all of which requires attention. As the impact of climate change threatens to escalate in the absence of adequate safeguards, there is a need to promote sustainability in the Malaysian POM for a more environment- and resource-friendly manner, not just for the future success of the firms, but for the health and well-being of future generations.

Notwithstanding differences in interpretation, the "sustainable" approach also plays an increasingly important role in research, not only agricultural and environmental but also within "sustainable production" or "sustainable manufacture" [10]. Previous studies of improving sustainability in palm oil manufacturing has been conducted, e.g., in the area of environmental impacts of palm oil production $[5,8]$, renewable energy applications of palm oil [11-13], utilisation of palm oil waste, and sustainable development and practices as detailed in the current research on POM. Research on opportunity and challenges in sustainability in the palm oil industry also have been explored [14-16]. However, studies on driving forces for sustainable manufacturing of palm oil have not being extensively published $[9,17,18]$. The noticeable lack of published research calls for research in this area. In an effort to enhance the growth of markets and reputation of Malaysian POM, the industry needs to realise the opportunity for change in POM systems and the drivers toward sustainability. Therefore, this paper will review the manufacturing perspective on the current sustainability effort, particularly in Malaysia, and identify the drivers that influence Malaysian POM for sustainability.
This paper is organized as follows: Section "Materials and Methods" presents the research materials and methods followed by stepwise evaluations. Section "Palm Oil Manufacturing" gives general POM information and production processes. Section "To-Date Research on Sustainability of Palm Oil Manufacturing" provides current research on POM referring to the relevant literature. Section "Drivers for Sustainability in Malaysian Palm Oil Manufacturing" discusses the drivers for POM sustainability in Malaysia. The paper ends with conclusions and recommendations for future research in "Conclusions."

\section{Materials and Methods}

Sustainability in Malaysian palm oil was studied and the research question arose: Why and how does Malaysian palm oil foster manufacturing sustainability? The study started with a literature review by analysing academic databases and palm oil academic journals. In particular, keyword-based research was carried out in the academic search engine ISI Web of Knowledge, Scopus SciVerse, and Google Scholar. The keywords used (combined with the word "palm oil") are: green, sustainable, sustainability, environment, manufacturing process. The recently published articles (ranging from 2000 to 2014) included books, conference publications, and journal articles that we reviewed and selected after verifying the relevancy of the contents based on preliminary skim reading of the abstracts and main body of the literature to provide insights into what has been done, why it has been done, and how it was done (as per Carnwell and Daly [19]).

In addition, relevant Malaysian regulations and laws supply important information that could be used for the study. These include Environmental Quality (Licensing) Regulations, Environmental Quality (Prescribed Premises) (Crude Palm Oil) Order, Environmental Quality (Sewage and Industrial Effluents) Regulations, Environmental Quality (Clean Air) Regulations, etc. [20]. National policies also play an important role in the sustainability of palm oil manufacturing. The policies reviewed in this study include various official regulations and reports published by major authorities such as Malaysia Standard Malaysian Sustainable Palm Oil (MSPO) by Department of Standards Malaysia, National Policy on Climate Change by Ministry of Natural Resources and Environment, National Green Technology Policy by Ministry of Energy, Housing and Local Government, Green Technology and Water, and National Policy for Solid Waste by Ministry of Urban Wellbeing, etc.

The review explored current research on Malaysian POM to identify the gap of knowledge and the drivers of manufacturing sustainability. Analysis of the literature further categorized the drivers into environmental consciousness, economic escalation, and social commitment. The linkage and elements of these drivers are discussed and presented. The findings will provide insight for Malaysian POM of the drivers for sustainability in manufacturing. 


\section{Palm Oil Manufacturing}

Palm oil manufacturing also known as palm oil mills, produces two types of oils: CPO from the fibrous mesocarp and crude palm kernel oil (CPKO) from the kernels as primary products and biomass as a secondary product. The analysis of the palm oil production process was based on the results of the reviewed literature [21-24]. The following processing steps are explained in the following and the process flow is summarized in Fig. 1.

Palm oil was extracted from the harvested bunches of ripe fruit. The FFBs were cooked in batches during sterilization for about 60-90 minutes. Sterilization inactivates the lipases in the fruits and prevents build-up of free fatty acids (FFA). The sterilization process using steam for the FFBs facilitated fruits being stripped from the fruit bunches and softened the fruit mesocarp for digestion and release of oil, and preparing of nuts to minimise breakage of the kernel. When the sterilization cycle was complete, the threshing process of separating the fruit from the bunch stalk in a horizontal rotating drum took place. Hard bunches of stalks that have fruits still attached to them had to be recycled to sterilizers for further cooking. The detached fruits passed through a bar screen in the stripper, collected by a bucket conveyor and sent into the digester. In the digester, the fruit was softened by a steam-heated cylindrical vessel fitted with central drum rotating at high temperature, between 80 and $90^{\circ} \mathrm{C}$, then the fruit mesocarp loosened from the nuts.

The fruits were pressed in single or multiple pressings using a screw press to enable more oil extraction. The mixture of oil, water, press cake, or fibre and nuts were discharged in the process, which then delivered to a clarifica- tion tank. The mixture containing the crude oil was diluted with hot water to reduce its viscosity. Next, the oil mixture was heated to $85-90^{\circ} \mathrm{C}$ and allowed to separate the solid and the oil in the clarification tank for settling time of 1 to 3 hours. Some of the solids are removed by a vibrating screen. Oil from the top is skimmed off and purified in the centrifuge prior to drying in a vacuum dryer for two hours to reach 0.1 to 0.5 percent moisture in the air. The final $\mathrm{CPO}$ was then cooled and stored. The bottom phase from the clarifier drained off as sludge of POME for further treatment before being discharged.

The cake from the screw presses were dried in the air column and the nuts were separated into the nut polishing drum, which frees the rest of the fibre, to be removed by strong air stream induced by suction fan. The fibres were sent to the boiler as fuel while the nuts were stored in silos to reduce moisture content from 16 to 11 percent by a stream of heated air. The nuts were then soaked in centrifugal nutcrackers, mostly of the self-grading type. The press cake from the digester was fed to a vertical column (depericarper) where the air was channelled to lift the fibre, thus separating the fibre from the nut. A nutcracker cracks the nuts after the conditioning and drying process. A ripple mill was also used instead of a nutcracker. The mixture of cracked nuts and shells was separated via a winnowing system, followed by a hydrocyclone or a clay bath. A hydrocyclone used centrifugal force to separate the kernel from the shell using water. The kernels were then dried in hot air silos to a moisture content of less than seven percent. The EFB, palm kernel shell, mesocarp fibres, and possibly solids from decanters are the solid palm oil waste. Fibre and shell - by-products from the milling process - were used as

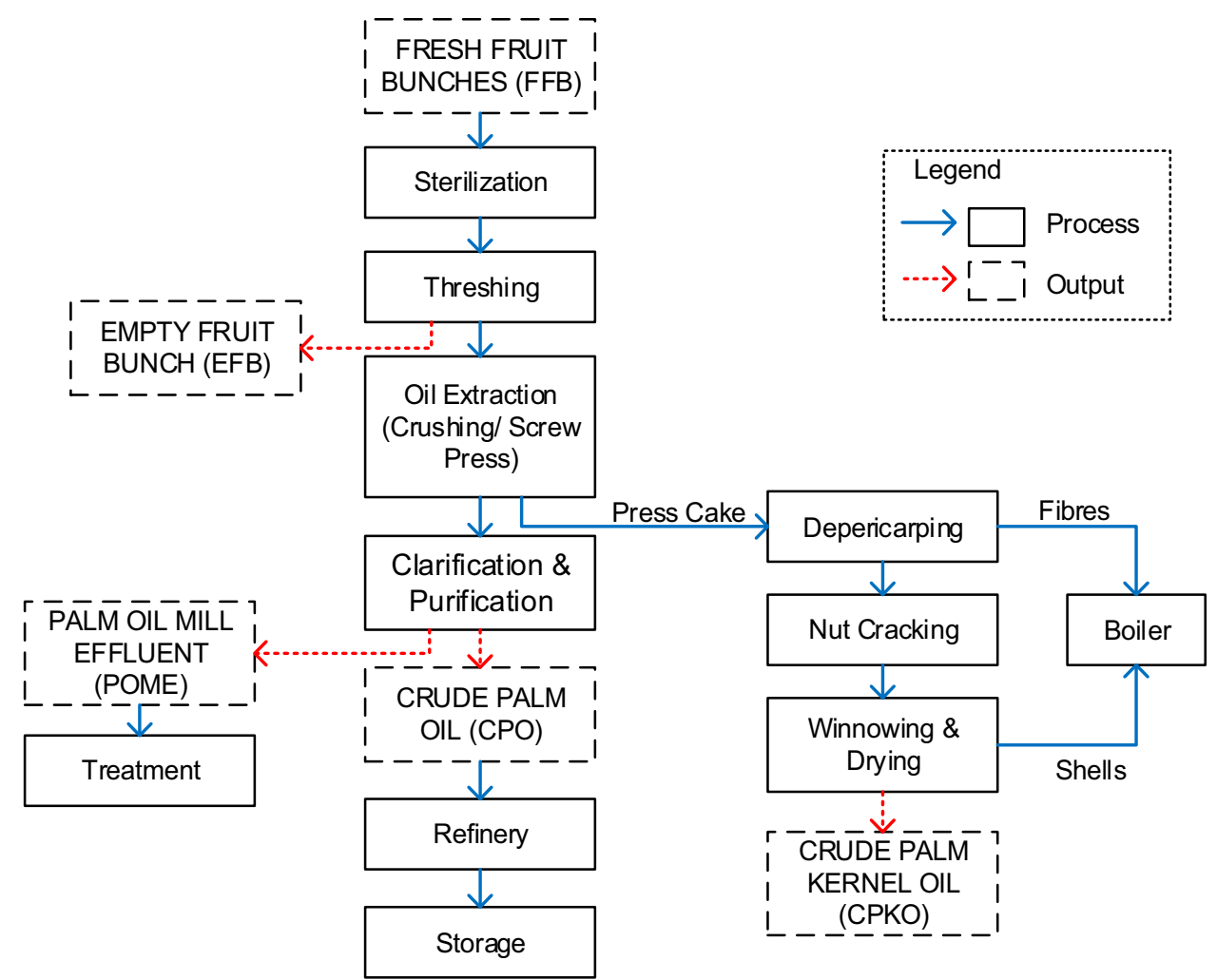

Fig. 1. Palm oil process flow. 
Table 1 . Sustainability palm oil manufacturing.

\begin{tabular}{|c|c|c|c|c|c|c|}
\hline \multirow{2}{*}{\multicolumn{2}{|c|}{ Sustainability }} & \multicolumn{5}{|c|}{ Manufacturing Process of Palm Oil } \\
\hline & & EFB & $\mathrm{CPO}$ & $\mathrm{CPKO}$ & Refinery & POME \\
\hline \multirow{9}{*}{ 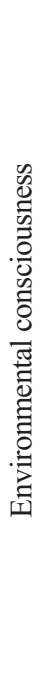 } & \multirow{5}{*}{$\begin{array}{l}\text { Laws, } \\
\text { regulations } \\
\text { and policies } \\
\text { compliance }\end{array}$} & \multicolumn{5}{|c|}{ Malaysian Environmental Quality Order and Regulations (refer Table 2) $[28,29]$} \\
\hline & & \multicolumn{5}{|c|}{$\begin{array}{l}\text { International standards and guidelines (e.g. including ISO 14000, Social Accountability (SA) 8000, ISO 26000, } \\
\text { Account Ability 1000, OECD Multinational Enterprises, Dow Jones Sustainability Index (DJSI) (2008), the } \\
\text { United Nations Global Compact, and World Business Council for Sustainable Development (WBCSD) [30] }\end{array}$} \\
\hline & & \multicolumn{5}{|c|}{ Carbon footprint labelling policy by SIRIM [31] } \\
\hline & & \multicolumn{5}{|c|}{ Green policies in Malaysia [32] } \\
\hline & & \multicolumn{5}{|c|}{ Malaysian Sustainable Palm Oil (MSPO) Part 4: General principles for palm oil mills [28] } \\
\hline & \multirow{3}{*}{$\begin{array}{l}\text { Waste } \\
\text { management } \\
\text { and pollution } \\
\text { control }\end{array}$} & \multirow{3}{*}{$\begin{array}{l}\text { Reverse logistics } \\
{[27,33-36]}\end{array}$} & LCA [22] & LCA [38] & LCA [42] & LCA [44] \\
\hline & & & \multirow{2}{*}{$\begin{array}{l}\text { GHG emissions } \\
{[23,37]}\end{array}$} & GHG emissions [39] & \multirow{2}{*}{ Zero waste $[43]$} & \multirow{2}{*}{$\begin{array}{l}\text { Reverse logistics } \\
{[5,11,14,25,45-50]}\end{array}$} \\
\hline & & & & Reverse logistics $[40,41]$ & & \\
\hline & $\begin{array}{c}\text { Technology } \\
\text { advancement }\end{array}$ & $\begin{array}{l}\text { New waste } \\
\text { treatment method } \\
{[41,51]}\end{array}$ & $\begin{array}{l}\text { New processes } \\
\text { method [52] }\end{array}$ & Energy generation $[18]$ & & $\begin{array}{l}\text { Technology of waste } \\
\text { treatment }[8,53-55]\end{array}$ \\
\hline \multirow{7}{*}{ 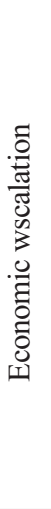 } & \multirow{2}{*}{$\begin{array}{l}\text { Market demand } \\
\text { growth }\end{array}$} & \multirow{2}{*}{$\begin{array}{l}\text { Renewable energy } \\
{[12,56,57]}\end{array}$} & \multicolumn{3}{|c|}{ Bioenergy and Oleochemicals [18] } & \\
\hline & & & \multicolumn{3}{|c|}{ Food products and industrial consumptions [58] } & \\
\hline & \multirow{2}{*}{$\begin{array}{l}\text { Brand and repu- } \\
\text { tation advantage }\end{array}$} & & \multicolumn{3}{|c|}{ RSPO certificate $[18]$} & \\
\hline & & & \multicolumn{3}{|l|}{ Eco-label [32] } & \\
\hline & \multirow{3}{*}{$\begin{array}{l}\text { Production } \\
\text { efficiency }\end{array}$} & & $\begin{array}{l}\text { Process } \\
\text { optimization [60] }\end{array}$ & Process improvement [63] & & \\
\hline & & & $\begin{array}{l}\text { Clean production } \\
\text { [61] }\end{array}$ & Energy Requirement [64] & & \\
\hline & & & $\begin{array}{l}\text { Energy efficiency } \\
\text { [62] }\end{array}$ & & & \\
\hline \multirow{5}{*}{ 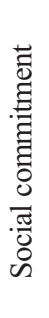 } & \multirow{4}{*}{ Labour welfare } & \multicolumn{5}{|c|}{ Safety and health policy (OSHA) 1994} \\
\hline & & \multicolumn{5}{|c|}{ Employment Act 1955 [65] } \\
\hline & & \multicolumn{5}{|c|}{ Factories and machinery (noise exposure) regulations 1989} \\
\hline & & \multicolumn{5}{|c|}{ Worker Minimum Standard of Housing and Amenities Act 1990} \\
\hline & $\begin{array}{l}\text { Community } \\
\text { wellbeing }\end{array}$ & \multicolumn{5}{|c|}{ Food safety and HACCP policy as per ISO 22000 [59] } \\
\hline
\end{tabular}

boiler fuel for producing steam at $17.57 \mathrm{~kg} / \mathrm{cm}^{2}$ gauge. Generation of electricity from the steam using steam turbines, and the low-pressure steam discharged from the turbines at $3.16 \mathrm{~kg} / \mathrm{cm}^{2}$ gauge is used for processing.

\section{To-Date Research on Sustainability of Palm Oil Manufacturing}

Analysis of published literature shows that the elements of sustainability - environmental consciousness, economic escalation, and social commitment - are the main area of research interest. In environmental consciousness, the drivers include laws, regulations, policy compliance, waste management and pollution control, and technology advancement. While market demand growth, brand and reputation advantage, and production efficiency are recognised as the drivers for POM economic sustainability, the drivers of social sustainability are labour welfare and community wellbeing. Current research on sustainability of POM covers the whole manufacturing system: EFB, CPO, CPKO, refinery, and POME management. POM sustainability mainly focuses on Malaysian and international acts, regulations and standards, reverse logistics, life cycle assessment (LCA), GHG emissions, zero waste, new degradation method, new processes method, energy generation, technology of POME treatment, renewable energy, RSPO certification, eco-label, bioenergy and oleochemicals, food products and industrial consumption, process optimization, clean production, energy efficiency, and process improvement as summarized in Table 1. 


\section{Empty Fruit Bunch}

The palm oil extraction process generated solid waste materials as well as byproducts, the most common of which is EFB [25]. Solid waste management is a global issue and has proven a key challenge facing many developing countries. It constitutes one of the most crucial health and environmental problems [26]. Chiew and Shimada [27] described the trend of reverse logistics of oil palm residue (i.e. the EFB left after extraction of the palm oil) using a case study of Malaysia, and discussed the environmental performance of recycling technologies being developed in Malaysia for fuel, fibre, and fertilizer. It concludes that to use EFB effectively for power generation, production costs would have to be lowered and major changes in the palm oil industry and fuel production capabilities would have to be made.

Sulaiman and Abdullah [33] determined the optimum conditions for maximising pyrolysis liquids of oil palm EFB for more efficient use of oil palm biomass. Shinoj et al. [34] compiled the research developments in the recent past on characterization of the fibre extracted from oil palm EFB, its utilization in bio composites, and their properties. It is found that oil palm fibre loading in some polymeric matrices improved the strength properties, whereas the strength of composite was less in some cases. Piarpuzán et al. [35] examined the feasibility of using EFB in ethanol production and evaluated the pre-treatment technology influence on sugar yield before enzymatic hydrolysis. Bari et al. [36] optimized the conventional media constituents supplemented with oil palm EFB as an additional source of sugar for citric acid production. Sisbudi et al. [21] presented results from a gate-to-gate analysis of the energy balance, GHG emissions, and economic efficiency of biochar production from oil palm EFB.

\section{Crude Palm Oil}

$\mathrm{CPO}$ is the main product for all oil palms obtained from the mesocarp and yielding around $15-18 \%$ of FFB processing. Bessou et al. [37] developed a GHG calculator using the LCA approach to quantify major sources of emissions and sequestration for individual palm oil mills and their supply base. PalmGHG can identify GHG emission "hot spots," and so help to define GHG reduction strategies. Subramaniam et al. [22] conducted a comparative study of GHG emissions from the production of CPO with and without allocation and biogas capture. GHG emissions from all sources are summed up and changed into units of $\mathrm{CO}_{2}$ equivalent, which was used to standardize GHG emissions. Conclusively, less than 10 percent of the palm oil manufacturing capture their biogas because palm oil manufacturing has excess energy from the biomass itself and invests in a large sum of money to harvest the biogas that will need the infrastructure to use or sell the harvested biogas.

Patthanaissaranukool et al. [66] evaluated energy and carbon equivalences associated with palm oil milling and sustainability alternatives for energy consumption. A field survey was carried out to quantify the input and output of energy and materials following the conceptual framework of a carbon-balanced model, which excluded other non$\mathrm{CO}_{2}$ greenhouse gases. The reverse logistics of palm oil biomass can have a significantly high potential as a resource to be used for climate change mitigation by reducing carbon emissions. Papong et al. [62] analysed the energy performance and potential of the palm oil methyl ester (PME) production in Thailand. The PME system was divided into four stages: the oil palm plantation, transportation, CPO production, and transesterification into biodiesel. The highest fossil-based energy consumption was in the transesterification process, followed by the plantation, transportation, and $\mathrm{CPO}$ production.

Subramaniam et al. [22] identified the potential environmental impacts associated with the production of CPO, and to evaluate opportunities to overcome the potential impacts. LCIA of the production of one tonne of $\mathrm{CPO}$ at the palm oil mill was examined. Chavalparit et al. [61] studied the nature of these industrial ecosystems, divided into plant ecosystems (clean technology options) and external waste exchange between $\mathrm{CPO}$ industries and other economic activities in Thailand. Amelia et al. [60] developed an optimisation model for palm oil production, therefore critical in ensuring maximum revenue in production while minimising palm oil and palm kernel losses and production cost. The optimisation method integrates a fuzzy expert system approach with a multi-objective programming model to maximise revenue, minimise total production cost, and minimise the total amount of CPO and palm kernel losses.

\section{Crude Palm Kernel Oil}

CPKO oil, also known as white palm oil, is obtained from the seed known as kernel or endo-sperm. When oil has been extracted from the kernel, what remains is known as palm kernel cake [25]. Mohd-Lair et al. [63] addressed the gap in the application of simulation modelling in improvement activities conducted on the POM. The application of simulation modelling in improving or evaluating potential improvements of palm kernel plant production process before the improvements are being carried out in the palm oil mill was demonstrated. Subramaniam et al. [38] consider the LCIA study of the production of one tonne of CPKO at the kernel-crushing plant. For this study, six kernelcrushing plants are chosen for their locations, which are well-distributed all over Peninsular Malaysia. Results indicate that the main impacts of upstream activities were from fertilizer production and application, and biogas emissions. The impacts directly associated with the production of CPKO are mainly from the transportation of palm kernels from the palm oil mills to the kernel-crushing plants and from the electricity consumption from the grid for the processing of the CPKO. The best scenario for the production of CPKO with the least environmental impact is when the kernel-crushing plant is integrated with a palm oil mill to capture the biogas. 
Fibres and shells are left over from palm oil production. The fibre is mostly used as solid fuel for boilers in palm oil manufacturing, while shells are sold as a solid fuel to other industries [25]. Arami-niya et al. [67] proposed optimisation of palm shell-based activated carbon production using a combination of chemical and physical activation for methane adsorption investigated using response surface methodology (RSM) in combination with central composite design. The objective was to optimise the preparation conditions of the oil palm shell for the adsorption of methane at low pressure for renewable fuel. Kum and Zahari [37] discussed the utilization of oil palm by-products (palm kernel expeller, palm oil sludge, palm pressed fibre, oil palm fronds, and oil palm trunks) as ruminant feed in Malaysia. Studies on the characterisation and their use in practical rations for beef and dairy production have been reported. Factors that can affect nutrient utilisation include the chemical and physical structure of the feeds, feed intake, and rate of passage and digestibility of the nutrients.

Husain et al. [38] highlighted that the fibre and much of the shell was used as fuel to generate process steam and electricity in the palm processing mill itself. However, much was wasted by burning them in the open air with attendant air pollution, dumped in areas adjacent to the mill, or utilized as manure in the palm oil plantation. An attempt was made to convert these residues into solid fuel. Subramaniam and Choo [36] quantified amounts to 583.20 $\mathrm{kg} \mathrm{CO}$ from the production of palm kernel at the mill, followed by the consumption of electricity from the grid for processing CPKO (which emits $74.33 \mathrm{~kg} \mathrm{CO}_{2}$ ) of the GHG emissions from the production of 1 tonne of CPKO at the kernel-crushing plant. Then the study showed that GHG emissions are reduced to $183.01 \mathrm{~kg} \mathrm{CO}_{2}$ compared with $678.73 \mathrm{~kg} \mathrm{CO}$ of the GHG emissions of 1 tonne CPKO with and without biogas capture at the palm oil mill for a kernel-crushing plant located near the ports, compared to a kernel-crushing plant located near the palm oil mill. Direct energy utilisation in nine palm-kernel oil mills located in southwestern Nigeria was analysed in Jekayinfa and Bamgboye [64] study. It identified the four most highly energy-intensive operations, including palm-nut cracking, palm-kernel roasting, palm-kernel crushing, and PKO expression - altogether accounting for 95.29, 92.14, and 93.65 percent of total energy used in small, medium, and large-scale mills, respectively.

\section{Refinery}

The refining process removes FFA, phosphatides, odoriferous matter, and water, as well as impurities such as dirt and traces of metals from the CPO. This process produced an edible oil of stable quality that meets industry standards and customer requirements, particularly in respect to FFA, moisture, impurities, iodine value, peroxide value, melting point, color, and flavour so that the refined oil must have a bland flavour [17].

Tan et al. [42] performed an LCA study on RPO, and its fractionated products were part of the sustainability solution provided by the Malaysian palm oil industry.
The greatest environmental burden arising from refining was from CPO, and consequently from RPO for fractionation to produce refined palm and palm stearin. This was followed by boiler fuel combustion and the transport of materials, suggesting that a potential mitigation measure for the reduction of GHG and consequently the impact on climate change would be to address these three inflows into the system. It was found that sourcing CPO from mills with systems in place for capturing biogas reduced the impact on climate change by about 40 percent. By adopting the use of LCA as part of the waste management decision-making process, countries can avoid the possibility of making serious long-term environmental mistakes [68]. Haslenda and Jamaludin [40] presented a systematic framework for optimal utilisation of by-products such as soap-stock, palm fatty acid distillate, and spent bleaching earth generated during CPO refining processes. The study formulated as mixed integer linear programming and integrated into the framework with the objective to maximize the refinery's profit as well as moving towards a conscious mind set of zero waste.

\section{Palm Oil Mill Waste}

The processing of oil palm FFB results in concomitant production of wastes in the form of POME, EFB, mesocarp fiber, and shell. POME is generated primarily from oil extraction, washing and cleaning processes, contains cellulosic material, fat, oil, and grease which may cause substantial environmental problems. Sisbudi et al. [45] assessed the use of POME as feedstock to produce biogas via anaerobic digestion. Biogas from POME can be converted into electricity and heat to eventually reduce the GHG emissions of biodiesel production from palm oil. Chin et al. [14] elaborated on the potential of POME as a source of renewable energy and the challenges faced by the POM in Malaysia, which deters the development of biogas plants in the mill. The study shows that the palm oil industry can be foreseen to continue its growing trend in the future, and POME can potentially become a sustainable source for biogas in Malaysia.

Rupani et al. [46] assessed the possibility of the vermicomposting of residue from the palm oil mills using epigeic earthworms Lumbricus rubellus under laboratory conditions. It advocated the candidature of POME for vermicomposting operation to address the issue of sustainability in industrial development. Balle et al. [47] study methane capture from the anaerobic digestion of POME in the pursuit of sustainable palm oil-derived biodiesel. If the methane was used for steam or electricity production, adding EFB to the POME could significantly increase gas production under thermophilic conditions. The author concludes that the implementation of solid waste treatment technologies such as waste incineration with energy recovery and pyrolysis also results in significant GHG reductions. Kalinci et al. [48] verified that oil palm wastes and EFB have on average specific energy values of 21.28 and $20.03 \mathrm{MJ} / \mathrm{kg}$, which indicate a good potential to produce energy - particularly heat and power in power plants. Foo and Hameed [5] presented 
a state-of-the-art review of the POME industry, its fundamental characteristics, and environmental implications. A key advance of the implementations and major challenges together with the future expectations were summarized and discussed. The expanding of POME in numerous fields of application represents a plausible and powerful circumstance for accruing the worldwide environmental benefit and shaping the national economy.

Singh et al. [25] emphasized in waste minimization at source or recycling waste produced from palm oil mills because improper waste management practice may also result in aesthetic problems and airborne diseases, and also may cause several vector-borne diseases. The study deals with various aspects of waste management practices in palm oil mills and the possibility of composting the wastes as these wastes are organic in origin and therefore rich in plant nutrients. Sulaiman et al. [49] catalogued palm oil production and consumption from 1976 to 2006, and the wastes available for potential utilisation. It concluded that utilisation of renewable energy resources, in particular oil palm wastes, is strategically viable as it can contribute to Malaysia's sustainable energy supply while minimising the negative impacts of energy generation on the environment. This will also solve the agriculture disposal problem in an environmentally friendly manner while recovering energy and higher value chemicals for commercial applications like bio-fuel, helping the government achieve its obligation to prolong fossil fuel reserves.

Wu et al. [50] considered the potential value of POME prior to its treatment through the introduction of cleaner production. It was envisaged that POME can be sustainably reused as a fermentation substrate in the production of various metabolites, fertilizers, and animal feeds through biotechnological advances. Various technically feasible and economically beneficial means of transforming the POME into low or preferably high-value-added products were discussed. Yusoff [11] described the effective use of biomass as the first of the renewable energy sources to be developed for large-scale applications, especially in the palm oil industry and the methodology for energy harness by the innovative utilisation of waste from palm oil cultivation and processing.

Ridzuan et al. [53] proposed a practical solution using activated carbon and selected coagulants for the zero emission of POME final discharge, using river water quality as the benchmark to meet river water quality for recycling and reuse of the POME final discharge as boiler feed water to fulfil the zero emission concept. By using this new proposed treatment the final chemical oxygen demand and suspended solids of residual water from the palm oil mill process are $10 \mathrm{mg} \cdot \mathrm{L}^{-1}$ and $2 \mathrm{mg} \cdot \mathrm{L}^{-1}$, respectively, which was better than river water quality. Therefore, the objective of zero emissions of POME final discharge can be achieved. Loh et al. [54] investigated the possibility of integrating several bioprocesses for POME treatment at the Malaysian POM by transforming the POME into several high-valueadded products, with biological oxygen demand $20 \mathrm{mg} \cdot \mathrm{L}^{-1}$ attainable at its final discharge. This integrated approach had the potential to achieve zero-effluent discharge along with the production of biogas, biofertiliser, and recycled water in treating industrial wastewater to reduce pollution.

Yeong et al. [55] discussed and compared state-of-theart POME treatment methods as well as their individual performances. The study also proposes wastewater management based on the promotion of cleaner production, and environmentally sound biotechnologies should be prioritized and included as part of the POME management in Malaysia for attaining sustainability. Shirai et al. [8] investigated the actual GHG emission from the lagoons and an open digesting tank in palm oil mills in order to establish the baseline for clean development mechanism project. Results indicated that methane contribution to biogass released from the open digesting tank and lagoon systems were 35 and 45 percent, respectively, which were much lower than the reported value of 65 percent obtained by the complete anaerobic condition of lab-scale experiments. Kalinci et al. [44] evaluated LCA of a palm oil production process, yielding both biodiesel and cooking oil, incorporating the land-use impact, and evaluating the effect of treating the POME prior to disposal.

\section{Drivers for Sustainability in Malaysian Palm Oil Manufacturing}

The drivers for sustainability in Malaysian POM are the major underlying causes of a changing industry and competitive conditions as the biggest influence on how the industry landscape altered sustainability. Identification and assessment of the drivers in Malaysian POM sustainability are essential for understanding the relationship between POM and sustainability. This section introduces the issue of drivers of sustainability by highlighting the findings emerging from literature review on the role played by drivers in defining POM orientation to sustainability, representing a way for explaining a firm's behaviour by conceiving sustainability as a behaviour adopted by firms. The drivers for Malaysian POM sustainability are illustrated in Fig. 2, focusing on three main standpoints: environmental consciousness, economic escalation, and social commitment. All these factors are expected to play a crucial role in contributing to the firm performance outcome.

\section{Environmental Consciousness}

Environmental consciousness among the top management of POM supports sustainability efforts in the organisation. It is driven by the waste management and pollution control practice that brings high-impact on the environment. Practicing reverse logistics in the organisation envisaged that POME can be sustainably reused as a fermentation substrate in the production of various metabolites, fertilizers, and animal feeds through biotechnological advances. Waste minimisation at source or recycling waste produced from palm oil mills because improper waste management practice may also result in aesthetic problems and airborne diseases, and also may cause several vector-borne diseases [25]. 
Utilisation of renewable energy resources, in particular oil palm wastes, and assessment of greenhouse gas emissions (GHG) through life cycle assessment (LCA). LCA is one of various management tools for evaluating environmental concerns and important as a decision-making support tool [69]. It is strategically viable as it can contribute to solve the waste disposal problem in an environmentally friendly manner while recovering energy and higher value chemicals for commercial applications [49]. Utilization of renewable energy resources, in particular oil palm wastes, is strategically viable as it can contribute to the POM sustainability of energy supply while minimizing the negative impacts of energy generation on the environment. It can also solve the agriculture disposal problem in an environmentally friendly manner while recovering energy and higher value chemicals for commercial applications like bio-fuel in helping the government to achieve its obligation to prolong fossil fuel reserves [70]. With the rising volume of palm oil residue accumulation due to palm oil production, palm biomass is gaining significant attention and being increasingly utilised to produce various green products as well as highly valuable biochemicals such as bioethanol, vitamins, etc. [32]. The oil palm biomass as non-food biomass from the mill is a great strategy toward zero discharge in the palm oil industry and minimizing greenhouse gas emissions [71].

Environmental consciousness also brings political pressure by stronger regulations for emissions and pollution [72]. Regulatory actions can often force significant changes in industry practices and strategic approaches of the palm oil business. Policy and regulation factors come from governments either through legislation or via a regulation requiring that companies adhere to certain environmental standards [73, 74]. The environmental restrictions in the industry provide a mechanism for permitting variable effluent standards [25], and legislation imposes limits on the nature and amounts of discharges to the atmosphere and waterways by mills and refineries [75]. Specifically, Malaysian laws regulating the palm oil industry [76] are presented in Table 2.

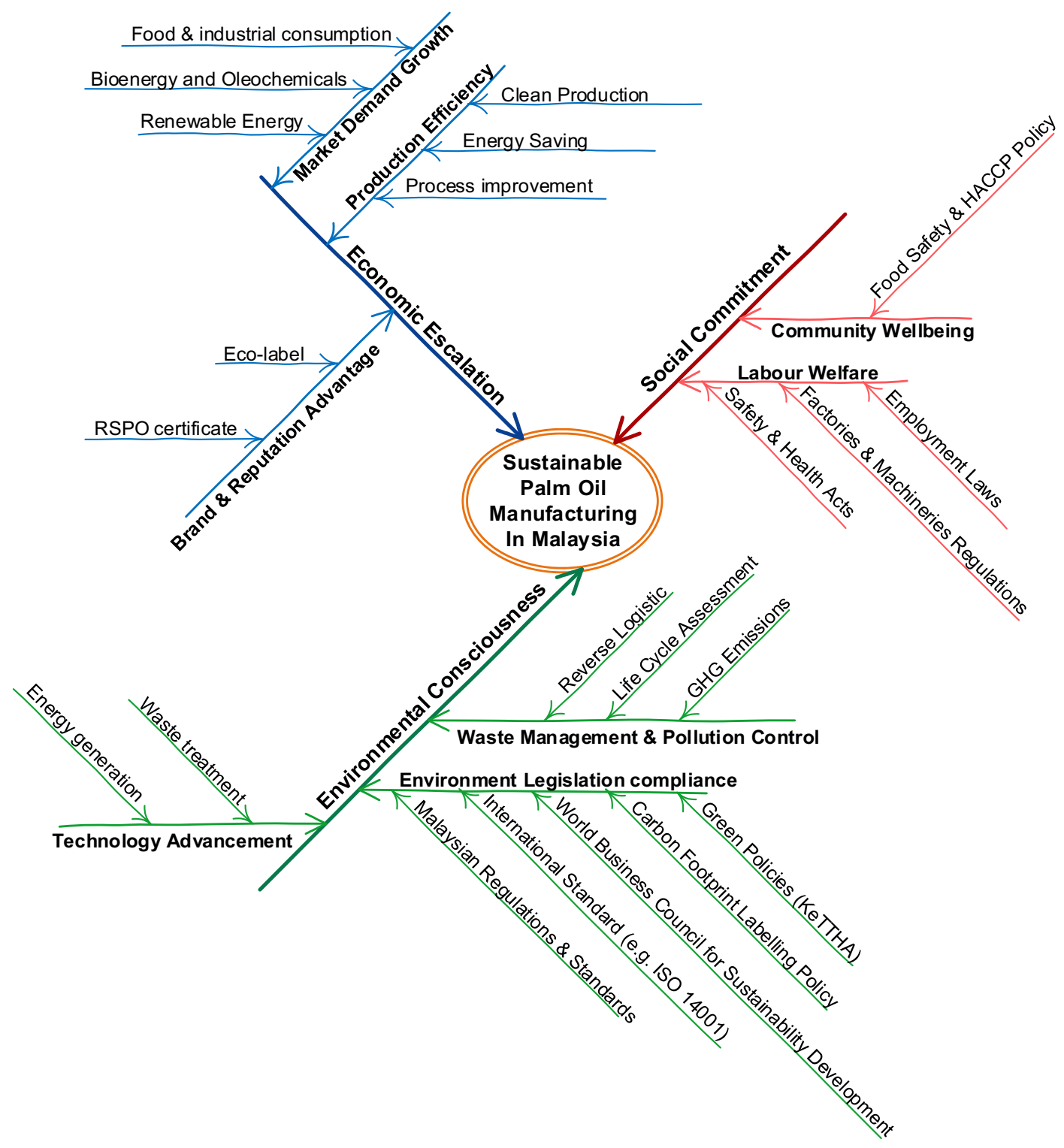

Fig. 2. Drivers for sustainability in Malaysian palm oil manufacturing. 
Table 2. Malaysian laws and standards regulating palm oil industry [28, 29].

\begin{tabular}{|c|c|}
\hline Principle & Malaysian Laws, Regulations, and Standards \\
\hline \multirow{4}{*}{$\begin{array}{l}\text { Control of agro-based water } \\
\text { pollution }\end{array}$} & Environmental Quality (Licensing) Regulations, 1977 \\
\hline & Environmental Quality (Prescribed Premises) (Crude Palm Oil) Order, 1977 \\
\hline & $\begin{array}{l}\text { Environmental Quality (Prescribed Premises) (Crude Palm Oil) Regulations, 1977, and (Amendment) } \\
1982\end{array}$ \\
\hline & Malaysian Sustainable Palm Oil (MSPO) Part 1: General principles \\
\hline \multirow{3}{*}{$\begin{array}{l}\text { Control of municipal and } \\
\text { industrial waste water pollution }\end{array}$} & Environmental Quality (Sewage and Industrial Effluents) Regulations, 1979 \\
\hline & Sabah Water Resource Enactment 1998 \\
\hline & Malaysian Sustainable Palm Oil (MSPO) Part 4: General principles for palm oil mills \\
\hline \multirow{2}{*}{ Control of industrial emissions } & Environmental Quality (Clean Air) Regulations, 1978 \\
\hline & Environmental Quality (Compounding of Offenses) Rules, 1978 \\
\hline \multirow{3}{*}{$\begin{array}{l}\text { Control of toxic and hazardous } \\
\text { waste management }\end{array}$} & Environmental Quality (Scheduled Wastes) Regulations, 1989 \\
\hline & $\begin{array}{l}\text { Environmental Quality (Prescribed Premises) (Scheduled Wastes Treatment and Disposal Facilities) } \\
\text { Order, } 1989\end{array}$ \\
\hline & $\begin{array}{l}\text { Environmental Quality (Prescribed Premises) (Scheduled Wastes Treatment and Disposal Facilities) } \\
\text { Regulations, } 1989\end{array}$ \\
\hline \multirow{2}{*}{ Biodiversity } & Sarawak Biodiversity Centre Ordinance 1997 \\
\hline & Sabah Biodiversity Enactment 2000 \\
\hline
\end{tabular}

The Ministry of Energy, Green Technology and Water (KeTTHA) is the main agency to promote green technology in Malaysia. It is responsible for the implementation of national policies relating to renewable energy and energy efficiency for sustainable development by granting increasingly attractive fiscal incentives for energy users to reduce production costs of doing business and to maintain a competitive edge in the international market. Malaysia's National Energy Policy aims to have an efficient, secure, and environmentally sustainable supply of energy, as well as the efficient and clean utilisation of energy [49]. Implementations of environmental management systems took place starting in 2004 and the National Life Cycle Assessment Project 2006. The implementation of carbon footprint labelling is currently being carried out under the National Carbon Footprint Labelling Scheme (2011-15) by the Standards and Industrial Research Institute of Malaysia (SIRIM) as part of continuous improvement in the delivery of sustainable palm oil products [31]. In addition, Malaysia has come up with Malaysian Standard Malaysian Sustainable Palm Oil [28], which is a national standard of sustainability.

There are international standards and guidelines as well for integrating sustainability management into business organizations. An increasing number of palm oil manufacturing adopted sustainability management-related standards and guidelines, including ISO 14000, Social Accountability (SA) 8000, ISO 26000, Account Ability 1000, Dow Jones Sustainability Index (DJSI) (2008), the United Nations Global Compact, and World Business Council for Sustainable Development (WBCSD) initiatives [30].
Emerging technologies also drive manufacturing sustainability [72]. From the perspective of palm oil processing firms, technological advancement may relate to efficient research and development efforts in the utilization of resources and creation of more diversified and new products. A promising area for applying technology to achieve more palm oil production sustainability is the use of organic waste material from palm kernel processing in energy generation [18]. The development of biogas plants could reduce waste and GHG emissions from decaying organic matter, and generate electricity for palm oil processing or other commercial or community activities [59]. In addition, the formulation of the crude POME discharge standards by phases has brought about the catalytic impact on the development of effluent treatment technology in the form of innovative or newly created technology [11]. The advancement in treatment technology has also seen the introduction of the decanter-drier system, which reduced the volume of clarification sludge by $75 \%$, while at the same time solids from POME using a rotary drier has also been harnessed [4]. This technology not only reducing the volume of effluent and has also reduced the problem of air pollution.

\section{Economic Escalation}

Manufacturing is on the way to overcome not only the existing limitations in performance, (which was the main objective to increase economic efficiency), but also to reduce the consumption of energy and material and emissions [72]. Energy is directly linked to the broader concept of sustainability and affects most of civilization since ener- 
gy resources drive much if not most of the world's economic activity, in virtually all economic sectors, e.g., industry and transportation. Resources of energy, whether carbon-based or renewable, are obtained from the environment, and wastes from energy processes including production, transport, storage, and utilization are released to the environment [71].

The palm oil industry may achieve economic escalation along with the development of greener production processes through cleaner production implementation and higher efficiency of utilisation of fuel, electricity, and labour, which suggests improving the operation for cleaner technology and less production cost [64, 77]. Furthermore, increased utilisation of renewable energy resources (in particular oil palm wastes) is strategically viable as it can contribute to the POM sustainability of energy supply while minimising the negative impacts of energy generation on the environment. It can also solve the agriculture disposal problem in an environmentally friendly manner while recovering energy and higher value chemicals for commercial applications like bio-fuel in helping the government to achieve its obligation to prolong fossil fuel reserves [70]. With the rising volume of palm oil residue accumulation due to palm oil production, palm biomass is gaining significant attention and is being increasingly utilised to produce various green products as well as highly valuable biochemicals such as bioethanol, vitamins, etc. [32]. The oil palm biomass as non-food biomass from the mill is a great strategy toward zero discharge in the palm oil industry and minimize greenhouse-gas emissions [71].

Other drivers, brand value, and reputation can be significantly enhanced by actions that improve a company's environmental and social performance. In emerging markets, where brands tend to be fairly weak, the brand owner's reputation can be a significant competitive factor [78]. Environmental concerns have progressively found diffusion among palm oil manufacturers and become strongly related to corporate image, and sustainability credentials are increasingly becoming an important criteria alongside price and quality when selecting palm oil suppliers [18]. Since the adoption of ISO 14000 standards, environmental labels or eco-labelling may help to promote the production of environmentally friendly products. The label helps consumers differentiate environmentally friendly products from conventional products and signifies the products' grade in the outlook on the environment [32, 79]. Increased access to export markets are a result of trade advantages arising from increased consumer demand for high-quality, environmentally friendly products - especially in highly developed countries. In addition, European Union legislation concerning eco-labels has also focused exporters' attention on the environmental aspects of their products [80]. Instead, unsustainable practices could damage reputations of organisations, including trading partners, with consumer backlash leading to boycotts and reduced sales, and increased media pressure, both locally and internationally, can erode brand value [81]. Adopting sustainability may increase palm oil companies' access to global markets, provide commercial opportunities, and enhance brand reputation. Gaining trust from markets and governments can also mean local or international expansion opportunities for POM as a preferred supplier.

\section{Social Commitment}

In Malaysia there is renewed interest in developing more effective oversight and accountability for corporate activities that impact society and the environment. The governments are executing policies in response to major sustainability issues, including greenhouse gas emissions, toxic chemicals, water use, labour, and human rights - particularly in the palm oil industry. POM are obliged to follow international and domestic policies to address issues that affect employees, whether socioeconomic issues (such as wages and healthcare), safety or environmental issues, and climate change. Safety and Health Policy (OSHA) 1994, Employment Act 1955, Factories and Machineries (Noise Exposure) Regulations 1989, and worker Minimum Standard of Housing and Amenities Act 1990 are the policies and law that the organizations have to follow. In addition, adopting food safety and HACCP policy as per ISO 22000 as the best developed practice for the palm oil industry is beneficial for community and customer well-being [59].

\section{Conclusions}

This paper presents the results from the literature study focus on current research in sustainability of Malaysian POM and drivers to embrace sustainability in POM, particularly in Malaysia. The exploration illustrates sustainability efforts in Malaysian POM concerning the field of the empty fruit bunch, crude palm oil, crude palm kernel oil, refinery process, and palm oil waste management. This study has highlight the relevance of some sustainability practices for the Malaysian POM, i.e., adoption of cleaner production, process improvement and optimisation, life cycle assessment, zero waste, and reverse logistics.

This paper also discloses the drivers of manufacturing sustainability of POM in Malaysia. The findings suggest that the three main standpoints that drive Malaysian POM for sustainability are environmental consciousness, economic escalation, and social commitment. By looking at environmental consciousness, elements of laws, regulations, and policy compliance, waste management and pollution control, and technology advancement regarding POM perceived a very promising field toward sustainability. Moving toward environmentally sustainable practices presents few or no risks to business operations but gains more benefits. If Malaysian POM acts at this instant and environmental sustainability continues to become an increasingly important and heavily regulated issue, they will have an advantage over many competitors. Besides some initial expenses involved in moving toward environmental sustainability, there are not likely to be any longterm negative impacts or expenses incurred. Subsequently, environmental consciousness drivers influencing the mar- 
ket demand growth, brand and reputation advantage, and production efficiency - the main elements of economic escalation drivers. Economic escalation driving Malaysian POM are perceived as a promising field as well in which POM organisation may increase their competitiveness, especially when facing international competition from economies with much lower production costs and higher utilisation of resources, including energy, materials, and labour. Besides, sustainable businesses may also have a competitive edge when it comes to attracting customers and investors. Thus, it is linked to the third drivers of sustainable POM in Malaysia, social commitment that includes labour welfare and community wellbeing.

Modern consumers are aware of social and environmental issues and keep informed about which businesses are acting responsibly in the community. Investors are equally aware of these issues and there is a trend developing toward investing in sustainable companies and opening up new opportunities to collaborate, develop products, and keep stakeholders happy and confident. This study also revealed that social commitment driving forces are highly relevant in realising sustainability, but a lesser amount of research has been published in this area. This indicates that there is still a large manufacturing sustainability gap to be bridged. This study helps palm oil organisations in Malaysia better understand the value of sustainability and to recognize their opportunities and threats in efforts to enhance business profiles and corporate reputations, and market growth without neglecting the environmental and social impacts.

Although the study incorporates extensive literature reviews, it does not capture every aspect of underlying construct characteristics. Therefore, it is important to extend the research in order to create more detailed survey and case study of the adoption of manufacturing sustainability practices and the perceived driving forces from Malaysian POM. Moreover, future work would explore further benefits of the sustainability for POM and develop a framework for performance measures and metrics for sustainability that will support the managers in making decisions regarding strategies, tactics, and operational policies and their impact on the outcome of sustainability within POM in Malaysia.

\section{Acknowledgements}

This research was co-funded by Universiti Teknikal Malaysia Melaka (UTeM) under an ERGS Grant (ERGS/1/2013/TK01/UTEM/02/08/E00029).

\section{References}

1. VALLANCE S., PERKINS H.C., DIXON J.E. What is social sustainability? A clarification of concepts. Geoforum 42, (3), 34, 2011.

2. NEJATI M., SHAHBUDIN A.S.B.M., AMRAN A Sustainable development: A competitive advantage or a threat? Bus. Strateg. Ser. 11, (2), 84, 2010.
3. YOSHIZAKI T., SHIRAI Y., HASSAN M.A., BAHARUDDIN A.S., RAJA ABDULLAH N.M., SULAIMAN A.,BUSU Z. Improved economic viability of integrated biogas energy and compost production for sustainable palm oil mill management. J. Clean Prod. 44, 1, 2013.

4. MALAYSIAN PALM OIL BOARD (MPOB). Oil Palm \& The Environment 1, 2012. Available at: www.mpob.gov.my/ en/palm-info/environment. Accessed July 27, 2014.

5. FOO K.Y., HAMEED B.H. Insight into the applications of palm oil mill effluent: A renewable utilization of the industrial agricultural waste. Renew. Sust. Energ. Rev. 14, (5), 1445, 2010.

6. FITZHERBERT E.B., STRUEBIG M.J., MOREL A., DANIELSEN F., BRÜHL C.A., DONALD P.F., PHALAN, B. How will oil palm expansion affect biodiversity? Trends Ecol. Evol. 23, (10), 538, 2008.

7. PLEANJAI S., GHEEWALA S.H. Full chain energy analysis of biodiesel production from palm oil in Thailand. Appl Energ. 86, (2009), S209, 2011.

8. SHIRAI Y., WAKISAKA M., YACOB S., HASSAN M.A., SUZUKI S.I. Reduction of Methane Released from Palm Oil Mill Lagoon in Malaysia and its Countermeasures. Mitig Adapt Strateg Glob Chang. 8, (3), 237, 2003.

9. STICHNOTHE H., SCHUCHARDT F. Life cycle assessment of two palm oil production systems. Biomass Bioenerg. 35, (9), 3976, 2011.

10. KRÓLCZYK J.B., LATAWIEC A.E., KUBOŃ M. Sustainable Agriculture - the potential to increase wheat and rapeseed yields in Poland. Pol. J. Environ. Stud. 23, (3), 663, 2014.

11. YUSOFF S. Renewable energy from palm oil e innovation on effective utilization of waste. J. Clean Prod. 14, 87, 2006.

12. MOHAMMED M.A.A., SALMIATON A., WAN AZLINA W.A.K.G, MOHAMMAD AMRAN M.S., FAKHRU'LRAZI A., TAUFIQ-YAP Y.H. Hydrogen rich gas from oil palm biomass as a potential source of renewable energy in Malaysia. Renew. Sust. Energ. Rev. 15, (2), 1258, 2011

13. UMAR M.S., JENNINGS P., URMEE T. Strengthening the palm oil biomass Renewable Energy industry in Malaysia. Renew. Energ. 60, 107, 2013.

14. CHIN M.J., POH P.E., TEY B.T., CHAN E.S., CHIN K.L. Biogas from palm oil mill effluent (POME): Opportunities and challenges from Malaysia's perspective. Renew. Sust. Energ. Rev. 26, 717, 2013.

15. NAGIAH C., AZMI R. A Review of smallholder oil palm production: Challenges and opportunities for enhancing sustainability - A Malaysian perspective. J. Oil Palm Environ. 3, (12), 114, 2012.

16. MURPHY D.J. Future prospects for oil palm in the 21st century: Biological and related challenges. Eur. J. Lipid Sci. Tech. 109, (4), 296, 2007.

17. TEOH CH. The Palm Oil Industry in Malaysia From Seed to Frying Pan.; 2002. Available at: assets.panda.org/downloads/ oilpalmchainpartaandb_esri.pdf. Accessed July 27, 2014.

18. ROUNDTABLE ON SUSTAINABLE PALM OIL (RSPO). Palm Oil in Australia: Facts, Issues and Challenges. 2013. Available at: www.rspo.org/file/PalmOilinAustralia.pdf? Accessed July 22, 2014.

19. CARNWELL R., DALY W. Strategies for the construction of a critical review of the literature. Nurse Educ Pract. 1, 57, 2001.

20. United Nations Economic and Social Commission for Asia and the Pacific (ESCAP). Mechanisms for integrating environmental considerations into agricultural policy. 2014. Available at: http://www.unescap.org/drpad/publication/ integra/volume3/malaysia/3my03d04.htm. Accessed July 27, 2014. 
21. SISBUDI S., GRUNDMAN P., HANG L., HANSEN A., AMRAN M., SALLEH M., MEYER-AURICH A., IDRIS A., IDATY T., GHAZI M. Resources, conservation and recycling energy balances, greenhouse gas emissions and economics of biochar production from palm oil empty fruit bunches. Resour. Conserv. Recy. 77, 108, 2013.

22. SUBRAMANIAM V., MAY C.Y., MUHAMMAD H., HASHIM Z., TAN Y., WEI P.C. Life cycle assessment of the production of crude palm oil (Part 3). J. Oil Palm Res. 22, 895, 2010.

23. SUBRAMANIAM V., MA A.N., CHOO Y.M. Capturing biogas: A means to reduce green house gas emissions for the production of crude palm oil. Am. J. Geosci. 1, (6), 1, 2010.

24. WICKE B., DORNBURG V., JUNGINGER M., FAAIJ A. Different palm oil production systems for energy purposes and their greenhouse gas implications. Biomass Bioenerg. 32, (12), 1322, 2008.

25. LEE K., FARZIPOOR R. Measuring corporate sustainability management: A data envelopment analysis approach. Int J. Prod. Econ. 140, (1), 219, 2012.

26. GUAN C., MCKAY A. Sustainability in the Malaysian palm oil industry. J. Clean Prod. 1, 2013.

27. PEI W., NG Q., LOONG H., YUEN F., KAMAL M., HENG J., LIM, E. Waste-to-wealth: Green potential from palm biomass in Malaysia. J. Clean Prod. 34, 57, 2012.

28. Malaysian Standard. Malaysian Sustainable Palm Oil (MSPO) Part 4: General principles for palm oil mills. 2013. Available at: http://www.msonline.gov.my/default.php. Accessed July 27, 2014.

29. CHIEW Y.L., SHIMADA S. Current state and environmental impact assessment for utilizing oil palm empty fruit bunches for fuel, fiber and fertilizer: A case study of Malaysia. Biomass Bioenerg. 51, 109, 2013.

30. SULAIMAN F., ABDULLAH N. Optimum conditions for maximising pyrolysis liquids of oil palm empty fruit bunches. Energy 36, (5), 2352, 2011.

31. SHINOJ S., VISVANATHAN R., PANIGRAHI S., KOCHUBABU M. Oil palm fiber (OPF) and its composites: A review. Ind. Crop. Prod. 33, (1), 7, 2011.

32. PIARPUZÁN D., QUINTERO J.A., CARDONA C.A. Empty fruit bunches from oil palm as a potential raw material for fuel ethanol production. Biomass Bioenerg. 35, (3), 1130, 2011.

33. BARI N., ALAM Z., MUYIBI S.A., JAMAL P. Improvement of production of citric acid from oil palm empty fruit bunches: Optimization of media by statistical experimental designs. Bioresource Technol. 100, (12), 3113, 2009.

34. BESSOU C., CHASE L.D.C., HENSON I. E., ABDULMANAN A.F.N., MILÀ L., AGUS F., SHARMA M., CHIN M. Pilot application of PalmGHG, the RSPO greenhouse gas calculator for oil palm products. J. Clean Prod. 73, 136, 2014.

35. SUBRAMANIAM V., MAY C.Y., MUHAMMAD H., HASHIM Z., TAN Y., WEI P.C. Life cycle assessment of the production of crude palm kernel oil (Part 3a). J. Oil Palm Res. 22, 904, 2010.

36. SUBRAMANIAM V., MAY C.Y. Greenhouse gas emissions for the production of crude palm kernel oil - A gate-togate case study. J. Oil Palm Res. 24, 1511, 2012.

37. KUM W., ZAHARI M.W. Utilisation of oil palm by-products as ruminant feed in Malaysia. J. Oil Palm Res. 23, 1029, 2011.

38. HUSAIN Z., ZAINAC Z., ABDULLAH Z. Briquetting of palm fibre and shell from the processing of palm nuts to palm oil. Biomass Bioenerg. 22, 505, 2002.
39. TAN Y.A., MUHAMMAD H., HASHIM Z., VIJAYA S., PUAH C.W., CHONG, C.L., MA A.N., CHOO, Y.M. Life cycle assessment of refined palm oil production and fractionation (Part 4). J Palm Oil Res. 22, 913, 2010.

40. HASLENDA H., JAMALUDIN M.Z. Industry to industry by-products exchange network towards zero waste in palm oil refining processes. Resour. Conserv. Recy. 55, (7), 713, 2011.

41. SISBUDI S., GRUNDMANN P., SOEBRONTO S. Anaerobic treatment of palm oil mill effluents: potential contribution to net energy yield and reduction of greenhouse gas emissions from biodiesel production. J. Clean Prod. 64, 619, 2014

42. RUPANI P., IBRAHIM M., ISMAIL S. Vermicomposting biotechnology: recycling of palm oil mill wastes into valuable products. Int. J. Recycl. Org. Waste Agric. 2, (1), 10, 2013.

43. BALLE S., IRVING S., UJANG Z. Bioresource technology greenhouse gas reductions through enhanced use of residues in the life cycle of Malaysian palm oil derived biodiesel. Bioresource Technol. 104, 358, 2012.

44. KALINCI Y., HEPBASLI A., DINCER I. Comparative exergetic performance analysis of hydrogen production from oil palm wastes and some other biomasses. Int. J. Hydrogen Energ. 36, (17), 11399, 2011.

45. SINGH R.P., IBRAHIM M.H., ESA N., ILIYANA M.S. Composting of waste from palm oil mill: a sustainable waste management practice. Rev. Environ. Sci Bio/Technology 9, (4), 331, 2010.

46. SULAIMAN F., ABDULLAH N., GERHAUSER H., SHARIFF A. A Perspective of oil palm and its wastes. J. Phys. Sci. 21, (1), 67, 2010.

47. WU T.Y., MOHAMMAD A.W., JAHIM J.M., ANUAR N. A holistic approach to managing palm oil mill effluent (POME): Biotechnological advances in the sustainable reuse of POME. Biotechnol. Adv. 27, (1), 40, 2009.

48. SAMSU A., SULAIMAN A., HEE D., NORIZNAN M., ALI M., WAKISAKA M. Selective component degradation of oil palm empty fruit bunches (OPEFB) using high-pressure steam. Biomass Bioenerg. 55, 268, 2013.

49. SCHUCHARDT F., WULFERT K., DARNOKO D., HERAWAN T. Effect of new palm oil mill processes on the EFB and POME utilisation. In: Proceedings of Chemistry and Technology Conference PIPOC 2007. Kuala Lumpur; 4457, 2007.

50. RIDZUAN M., ALI M., SHIRAI Y., SAMSU A., AMIRUDDIN A., IDRIS J. Treatment of ef fl uents from palm oil mill process to achieve river water quality for reuse as recycled water in a zero emission system. J. Clean. Prod. 67, 58, 2014.

51. LOH S.K., LAI M., NGATIMAN M., LIM W.S., CHOO Y.M. Zero discharge treatment technology of palm oil mill effluent. J. Oil Palm Res. 25, (3), 273, 2013.

52. YEONG T., WAHAB A., JAHIM J., ANUAR N. Pollution control technologies for the treatment of palm oil mill effluent (POME) through end-of-pipe processes. J. Environ Manage. 91, (7), 1467, 2010.

53. ELMER U., NYGAARD I. Sustainable energy transitions in emerging economies: The formation of a palm oil biomass waste-to-energy niche in Malaysia 1990-2011. Energ. Policy 66, 666, 2014.

54. CHIEW Y.L., IWATA T., SHIMADA S. System analysis for effective use of palm oil waste as energy resources. Biomass Bioenerg. 35, (7), 2925, 2011.

55. United States Department of Agriculture (USDA). Palm oil production, exports and imports by country. 2010. Available at: http://www.indexmundi.com/agriculture/. 
56. AMELIA L., WAHAB D.A., HASSAN A. The application of hybrid artificial intelligence techniques in the optimisation of crude palm oil production. In: International Symposium on Information Technology, 2008. ITSim 2008, (1). IEEE: 1-9, 2008.

57. CHAVALPARIT O., RULKENS W.H., MOL A.P.J., KHAODHAIR S. Options for environmental sustainability of the crude palm oil industry in Thailand through enhancement of industrial ecosystems. Environ Dev Sustain. 8, (2), 271, 2006

58. PAPONG S., CHOM-IN T., NOKSA-NGA S., MALAKUL P. Life cycle energy efficiency and potentials of biodiesel production from palm oil in Thailand. Energ. Policy 38, (1), 226, 2010.

59. MOHD-LAIR N-A., LEE J.F-M., LIEW W.Y.H., SARBATLY R. Simulation based process improvement in palm oil industry: A case study at palm kernel department. In Business Engineering and Industrial Applications Colloquium (BEIAC), 2012 IEEE, pp. 12-15. IEEE, 2012.

60. JEKAYINFA SO., BAMGBOYE AI. Energy requirements for palm-kernel oil processing operations. Nutr. Food Sci. 34, (4), 166, 2004.

61. Laws of Malaysia. EMPLOYMENT ACT 1955 (Act 265). 2012; (April). Available at: http://www.agc.gov.my/Akta/ Vol. 6/Act 265.pdf. Accessed July 27, 2014.

62. WENG C.K. Best-developed practices and sustainable development of the oil palm industry. J. Oil. Palm Res. 17, 124, 2005.

63. KADAFA A.A., MANAF L.A., NUR W., SULAIMAN A. Applications of system analysis techniques in solid waste management assessment. 23, (4), 1061, 2014.

64. PATTHANAISSARANUKOOL W., POLPRASERT C., ENGLANDE A.J. Potential reduction of carbon emissions from crude palm oil production based on energy and carbon balances. Appl. Energ. 102, 710, 2013.

65. ARAMI-NIYA A., MOHD W., WAN A., MJALLI F.S., ABNISA F. Chemical engineering research and design production of microporous palm shell based activated carbon for methane adsorption: Modeling and optimization using response surface methodology. Chem. Eng. Res. Des. 90, (6), 776, 2012

66. SAHERI S., MIR M.A., BASRI N.E.A., MAHMOOD N.Z.B., BEGUM R.A. Life cycle assessment for solid waste disposal options in Malaysia. Pol. J. Environ. Stud. 21, (5), 1377, 2012.

67. ACHTEN W.M.J., VANDENBEMPT P., ALMEIDA J., MATHIJS E., MUYS B. Life cycle assessment of a palm oil system with simultaneous production of biodiesel and cooking oil in Cameroon. Environ. Sci Technol. 44, (12), 4809, 2010.
68. LEWANDOWSKA A., FOLTYNOWICZ Z. New Direction of development in environmental life cycle assessment. Pol. J. Environ. Stud. 13, (5), 4632004.

69. SULAIMAN F., ABDULLAH N., GERHAUSER H., SHARIFF A. An outlook of Malaysian energy, oil palm industry and its utilization of wastes as useful resources. Biomass Bioenerg. 35, (9), 3775, 2011.

70. HASSAN M.A., YEE L.N., YEE P.L., ARIFFIN H., RAHA A.R., SHIRAI Y., SUDESH K. Sustainable production of polyhydroxyalkanoates from renewable oil-palm biomass. Biomass Bioenerg. 50, 1, 2012.

71. WESTKÄMPER E. Manufuture and sustainable manufacturing. In: Manufacturing systems and technologies for the new frontier. Springer: London, pp. 11-14, 2008.

72. GRZESIK K. Waste management plans: Tools for sustainable development. Pol. J. Environ. Stud. 14, (5),703, 2005.

73. HASSINI E., SURTI C., SEARCY C. A literature review and a case study of sustainable supply chains with a focus on metrics. Int. J. Prod. Econ. 140, (1), 69, 2012.

74. WAHID M.B., NOR S., ABDULLAH A., HENSON I.E. Oil Palm - Achievements and Potential. In: Proceedings of the $4^{\text {th }}$ International Crop Science Congress. Brisbane, Australia. 1-13, 2004.

75. Malaysian Palm Oil Board (MPOB). Malaysian Laws Regulating Palm Oil Industry. PALMOILIS Portal. 2014. Available at: http://palmoilis.mpob.gov.my/index.php/ malaysian-laws-regulating-palm-oil-industry. Accessed July 27, 2014.

76. Malaysian Standard. Malaysian Sustainable Palm Oil (MSPO) Part 1: General principles. 2013. Available at: http://www.msonline.gov.my/default.php. Accessed July 27, 2014.

77. ZENG S.X., MENG X.H., YIN H.T., TAM C.M., SUN L. Impact of cleaner production on business performance. $\mathrm{J}$. Clean Prod. 18, (10), 975, 2010.

78. THORPE J, PRAKASH-MANI K. Developing value: The business case for sustainability in emerging markets. Manag. Bus. Case Sustain. Integr. Soc. Environ. Econ. Perform. 1, (62), 444, 2006.

79. MATUSZAK-FLEJSZMAN A. Benefits of Environmental management system in polish companies compliant with ISO 14001. Pol. J. Environ. Stud. 18, (3), 411, 2009.

80. WYSOKIŃSKA Z, WITKOWSKA J. International Business and Environmental Issues - Some Empirical Evidence from Transition Economies; 14, (3), 269, 2005.

81. World Wildlife Fund (WWF). Palm Oil Investor Review: Investor Guidance on Palm Oil The Role of Investors in Supporting the Development of a Sustainable Palm Oil Industry. 2012. Available at: http://wwf.panda.org/what we_do/footprint/agriculture/palm_oil// solutions/responsible financing/investor_review/.81. Accessed July 27, 2014. 
